\title{
Iron overload in myelodysplastic syndromes (MDS)
}

\author{
Norbert Gattermann ${ }^{1}$
}

Received: 29 October 2017 / Accepted: 8 November 2017 / Published online: 25 November 2017

(c) The Japanese Society of Hematology 2017

\begin{abstract}
Iron overload (IOL) starts to develop in MDS patients before they become transfusion-dependent because ineffective erythropoiesis suppresses hepcidin production in the liver and thus leads to unrestrained intestinal iron uptake. However, the most important cause of iron overload in MDS is chronic transfusion therapy. While transfusion dependency by itself is a negative prognostic factor reflecting poor bone marrow function, the ensuing transfusional iron overload has an additional dose-dependent negative impact on the survival of patients with lower risk MDS. Cardiac dysfunction appears to be important in this context, as a consequence of chronic anemia, age-related cardiac comorbidity, and iron overload. Another potential problem is iron-related endothelial dysfunction. There is some evidence that with increasing age, high circulating iron levels worsen the atherosclerotic phenotype. Transfusional IOL also appears to aggravate bone marrow failure in MDS, through unfavorable effects on mesenchymal stromal cells as well a hematopoietic cells, particularly erythroid precursors. Patient series and clinical trials have shown that the iron chelators deferoxamine and deferasirox can improve hematopoiesis in a minority of transfusion-dependent patients. Analyses of registry data suggest that iron chelation provides a survival benefit for patients with MDS, but data from a prospective randomized clinical trial are still lacking.
\end{abstract}

Keywords Myelodysplastic syndrome · Chronic transfusion therapy $\cdot$ Iron overload $\cdot$ Iron chelation $\cdot$ Deferasirox

\section{Introduction}

Iron overload (IOL) in MDS starts before patients become transfusion-dependent because ineffective erythropoiesis suppresses hepcidin production in the liver and thus leads to unrestrained intestinal iron uptake [1]. However, the most important cause of iron overload in MDS is chronic transfusion therapy. A patient requiring $4 \mathrm{RBC}$ units per months will receive 100 units over 2 years, equivalent to at least $20 \mathrm{~g}$ of iron. Transfusional iron overload can hardly be avoided in MDS because anemia must be ameliorated to increase the quality of life and decrease the probability of non-leukemic death, particularly from cardiac complications, which is dramatically increased in male MDS patients with a $\mathrm{Hb}<9 \mathrm{~g} /$ $\mathrm{dl}$, and female MDS patients with a hemoglobin $<8 \mathrm{~g} / \mathrm{dl}$ [2].

Norbert Gattermann

gattermann@med.uni-duesseldorf.de

1 Department of Hematology, Oncology and Clinical Immunology, Heinrich Heine University Düsseldorf, Düsseldorf, Germany
Unfortunately, the concomitant development of transfusional iron overload can have untoward effects.

\section{Clinical consequences of iron overload in MDS}

It has been shown that iron overload has a dose-dependent negative impact on the survival of patients with lower risk MDS [2]. Although higher serum ferritin (SF) levels may simply reflect greater transfusion need, indicating the severity of bone marrow disease as the real cause of shorter survival, it was also shown that SF is an independent prognostic factor, even if transfusion burden is taken into account on multivariate analysis by including the number of transfusions per month as a covariate. Under these transfusionadjusted conditions, there was still a $30 \%$ greater risk of death for every $500 \mu \mathrm{g} / \mathrm{l}$ increase in SF above a threshold of $1000 \mu \mathrm{g} / 1$ [3]. Similarly, data from the European LeukemiaNet prospective MDS registry indicated that, besides transfusion burden, increasing SF levels had independent impact 


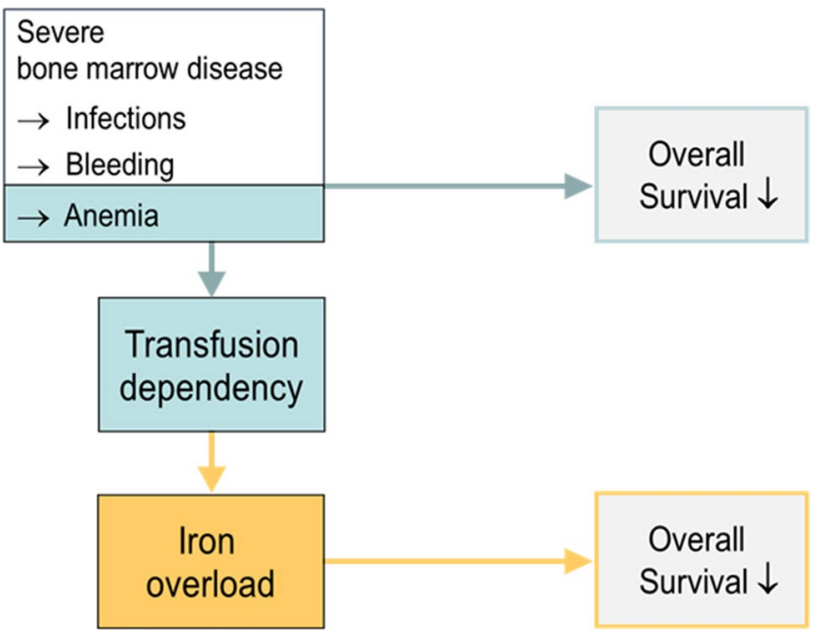

Fig. 1 Relationship between bone marrow failure, iron overload and prognosis in patients with MDS

on the overall survival of transfusion-dependent patients with lower risk MDS [4].

As depicted in Fig. 1, transfusion dependency is linked with shortened survival because it reflects severe bone marrow disease with all its possible complications. At the same time, transfusion dependency causes iron overload and thus creates a new medical problem that has a negative impact on survival, too. The relative weight of these two risk factors may vary considerably. A patient with sideroblastic anemia (RARS) is unlikely to die from infections or bleeding but may indeed develop complications from transfusional IOL. In contrast, a patient with RAEB-I or -II, despite similar transfusion dependency, may not have the time to develop such complications because survival is limited by other aspects of bone marrow failure.

Cardiac dysfunction appears to be important in this scenario, as a consequence of chronic anemia, age-related cardiac comorbidity, and iron overload. Cardiac iron overload in MDS is detectable by MRI after transfusion of 75-100 units of RBC. A British group found that $81 \%$ of regularly transfused MDS patients had iron overload in the liver and $16.8 \%$ in the heart [5]. Similarly, a French study [6] found cardiac iron overload in $18.2 \%$ of the patients, with a linear correlation between the $\mathrm{T} 2 *$ values and the number of RBC units transfused. On echocardiography, severe cardiac dysfunction with a LVEF $\leq 35 \%$ was found in $27 \%$ of patients with $\mathrm{T} 2 * \leq 20 \mathrm{~ms}$, but only 1 of 46 patients with T2* $>20 \mathrm{~ms}$. The authors concluded that iron overload can be a significant aggravating factor in the pathophysiology of cardiac failure in MDS, in addition to chronic anemia and comorbidities.

Heart failure, like other iron-related organ damage, may not only depend on tissue iron concentrations but also on the duration of chronic exposure to non-transferrin-bound iron and labile plasma iron because the latter generate oxidative stress. A patient with a SF of $2500 \mathrm{ng} / \mathrm{ml}$ has not only accumulated more iron but may also have had longer exposure to elevated reactive oxygen species (ROS) than a patient with a SF level of $1500 \mathrm{ng} / \mathrm{ml}$. We should also be aware that the heart is more vulnerable to iron toxicity than the liver, which is reflected by the fact that clinically relevant cardiac dysfunction occurs at much lower tissue iron concentrations than clinically relevant liver dysfunction $[7,8]$.

Another potential problem is iron-related endothelial dysfunction. There is some evidence that with increasing age, high circulating iron levels worsen the atherosclerotic phenotype [9]. Macrophages in the vessel wall can accumulate iron from increased destruction of RBCs or by disturbed iron homeostasis, leading to increased production of ROS and decreased efflux of cholesterol. The resulting oxidative stress and LDL accumulation promote the formation of foam cells, inflammation, apoptosis, and eventually plaque destabilization. Accordingly, benefit may be derived from iron chelation. Fifteen years ago, it was shown that iron chelation improves endothelial function in patients with coronary artery disease [10]. Deferoxamine improved nitric-oxidemediated, endothelium-dependent vasodilation, suggesting that iron availability contributes to impaired nitric-oxide action in atherosclerosis. A favorable effect of iron chelation on arterial function has also been reported in patients with beta-thalassemia major, where deferasirox significantly improved brachial artery flow-mediated dilation and significantly decreased the carotid arterial stiffness index. This was attributed to the binding of labile cellular iron in the vascular wall, thereby attenuating reactive oxygen species formation and nitric oxide inactivation [11].

The connection between iron and endothelial dysfunction illustrates that iron-related complications overlap with age-related clinical problems (Fig. 2). Iron overload has the

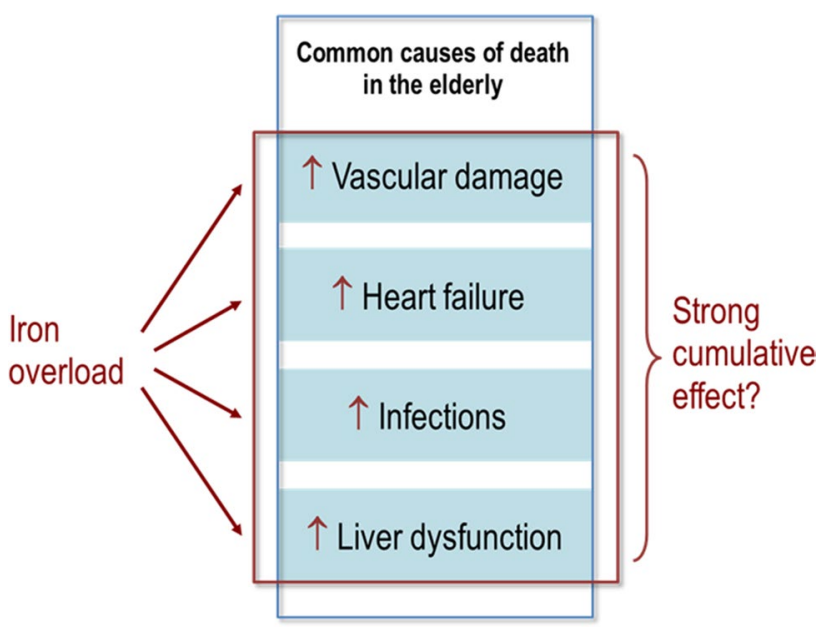

Fig. 2 Overlap between iron-related complications and common agerelated medical problems 
potential to simultaneously aggravate several age-related pathologies, which may add up to a strong cumulative effect. However, this effect may be largely obscured by the common causes of death in the elderly. Therefore, it is rather difficult to determine the extent to which iron overload contributes to morbidity and mortality in elderly MDS patients.

\section{Iron overload and bone marrow function}

Ineffective erythropoiesis causes anemia and transfusion dependency, leading to transfusional IOL, which may in turn aggravate bone marrow failure in MDS. Figure 3 illustrates where IOL may have an aggravating effect on MDS pathophysiology. Experimental evidence indicates that IOL contributes to stromal dysfunction $[12,13]$ and exacerbates genomic instability, thereby hastening clonal evolution towards leukemia.

MDS patients show increased levels of oxidative stress, which is further aggravated by iron overload [14-21]. The resulting oxidative DNA damage, worsened by iron overload [22], may contribute to mutagenesis in the bone marrow. Investigations into the effects of iron overload on genomic instability in MDS support the idea that IOL contributes to genomic instability [23]. The data also suggest that SF levels not only above 1000 but also between the upper limit of normal and 1000, adversely affect genetic stability. Therefore, iron chelation might be relevant for patients with MDS at lower SF levels than previously thought. The fact that hereditary hemochromatosis and thalassemia major are not associated with an increased incidence of MDS and AML suggests that IOL by itself does not transform normal hematopoietic stem cells into pre-leukemic stem cells. However, proliferating stems cells that have already acquired genomic instability from other causes seem to be vulnerable to the additional genotoxic stress from iron overload.

Increased oxidative stress appears to be particularly detrimental to erythroid progenitors, which show impaired proliferation even at moderately elevated SF values, whereas the number of granulopoietic colonies is largely unaffected [24]. The vulnerability of erythroid precursors may be due to the fact that both the TfR-deficient mature RBC and their TfR-containing precursors can take up non-Tf iron during iron overload [25]. The incoming non- $\mathrm{Tf}$ iron does not participate in heme synthesis and $\mathrm{Hb}$ production but induces the generation of ROS, resulting in cytotoxicity. This effect, suppressing the formation of BFU-E and their differentiation to mature erythroblasts, can be canceled by iron chelation with deferoxamine [26].

Iron overload also caused stromal dysfunction in a mouse model [12]. BM transplantation from normal donor mice to IOL recipients resulted in delayed hematopoietic reconstitution, indicating that excess iron disturbed the hematopoietic microenvironment. Also in mice, IOL impaired the proliferation of mouse BM mesenchymal cells, and free ironcatalyzed oxidative damage to mesenchymal cells in vitro, thereby attenuating hematopoiesis [13].

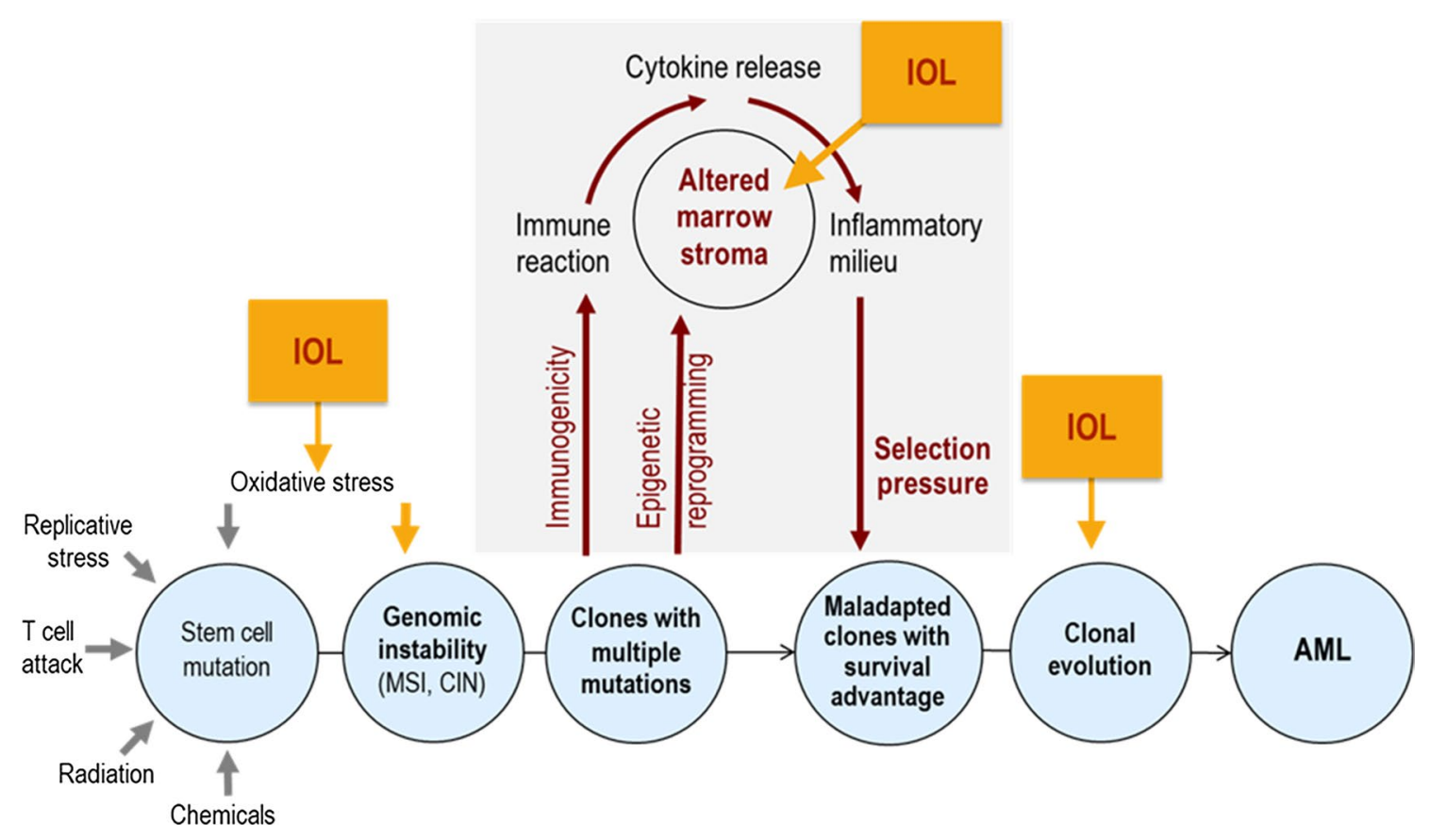

Fig. 3 Possible role for iron overload (IOL) in the pathophysiology of myelodysplastic syndromes 
A number of case reports, small patient series, and larger studies showed that the iron chelator deferasirox can improve hematopoiesis in MDS. Table 1 includes the largest studies conducted so far. Erythroid response rates range between 11 and $22 \%$.

Table 1 Clinical trials showing erythropoietic improvement during iron chelation therapy in patients with lower risk MDS [27-30].

Using strict criteria for erythroid response, a prospective Italian multicenter study found that during 12 months of treatment with DFX, RBC transfusion requirement declined significantly from a median of 3 to a median of $1 \mathrm{RBC}$ units per month [30]. The cumulative incidence of transfusion independence increased from $2.6 \%$ at 6 months to $15.5 \%$ at 12 months.

This effect is not a novel phenomenon. About 20 years ago, Jensen et al. [31] reported remarkable improvement of hemopoiesis when $11 \mathrm{MDS}$ patients with transfusional IOL were followed for up to 5 years during and after treatment with deferoxamine (DFO). A greater than $50 \%$ reduction in transfusion requirement was observed in 7 of 11 patients, and 5 patients became transfusion independent. Since this was achieved with DFO, hematological response does not seem to depend on a particular iron chelator. It appears to be more important to keep patients well chelated over a long time. Long-term suppression of oxidative stress may improve hematopoietic support by the bone marrow stroma and may also slow down the pace of clonal genetic evolution.

\section{Is there a survival benefit from chelation therapy (ICT)?}

Numerous studies suggest that iron chelation improves survival in TD-MDS (Table 2).
Table 1 Clinical trials showing erythropoietic improvement during iron chelation therapy in patients with lower risk MDS [27-30]

\begin{tabular}{lllll}
\hline Study & Risk IPSS & RBC response & Neutrophil response & PLT response \\
\hline List et al. [27] & Low/lnt-1 & $15 \%(n=173)$ & $15 \%(n=52)$ & $22 \%(n=77)$ \\
Gattermann et al. [28] & Low/lnt-1 & $21.5 \%(n=247)$ & $22 \%(r=50)$ & $13 \%(n=100)$ \\
Nolte et al. [29] & Low/lnt-1 & $11 \%(n=50)$ & NR & NR \\
Angelucci et al. [30] & Low/lnt-1 & $\begin{array}{c}\text { Transfusion independ- } \\
\text { ence in 15.5\% }(n=\end{array}$ & NR & NR \\
& & $152)$ &
\end{tabular}

Table 2 Clinical studies showing that iron chelation improves survival in patients with lower risk MDS [32-40]

\begin{tabular}{|c|c|c|c|c|c|c|}
\hline Study & $N$ & Design & Survival & Non-chelated patients & Chelated patients & $p$ value \\
\hline \multirow[t]{2}{*}{ Leitch et al. [63] } & \multirow[t]{2}{*}{36} & \multirow[t]{2}{*}{ Retrospective } & Median OS & 40 months & Not reached & 0.003 \\
\hline & & & 4-year survival rate & $43 \%$ & $64 \%$ & 0.003 \\
\hline \multirow[t]{2}{*}{ Rose et al. [33] } & \multirow[t]{2}{*}{97} & \multirow[t]{2}{*}{ Prospective follow-up } & $\begin{array}{l}\text { Median OS from diag- } \\
\text { nosis }\end{array}$ & 53 months & 124 months & $<0.0003$ \\
\hline & & & $\begin{array}{l}\text { Median OS with adequate } \\
\text { vs weak chelation }\end{array}$ & NA & 124 vs. 85 months & $<0.001$ \\
\hline Neukirchen et al. [34] & 188 & Matched pair analysis & Median OS & 49 months & 75 months & 0.002 \\
\hline Neukirchen et al. [35] & 417 & Retrospective, registry & $\begin{array}{l}\text { Median time to death in } \\
\text { TD patients }\end{array}$ & 30 months & 67 months & NR \\
\hline Komrokji et al. [36] & 97 & Retrospective & Median OS & 34 months & 59 months & 0.013 \\
\hline \multirow[t]{3}{*}{ Zeidan et al. [37] } & \multirow[t]{3}{*}{4.226} & \multirow[t]{3}{*}{ Retrospective, registry } & Median survival & 47 week & 110 weeks & 0.003 \\
\hline & & & $\begin{array}{l}\text { HR for } 27-52 \text { weeks on } \\
\text { DFX }\end{array}$ & 1 & 0.77 & NR \\
\hline & & & $\begin{array}{l}\text { HR for } \geq 53 \text { weeks on } \\
\text { DFX }\end{array}$ & 1 & $\mathrm{CM}$ & NR \\
\hline Langemeijer et al. [41] & 765 & Prospective, registry & Adjusted HR & $1.6(1.2-2.3)$ & 1 & 0.006 \\
\hline Delforge et al. [38] & 127 & Retrospective & Median OS in Low/lnt-1 & 3.1 years & 10.2 years & $<0.001$ \\
\hline Lyons et al. [39] & 600 & Prospective, registry & $\begin{array}{l}\text { Median OS from diag- } \\
\text { nosis }\end{array}$ & 47.8 months & $\begin{array}{l}\text { All } 88.0 \text { months } \\
\text { ICT }>6 \text { months } 100.0 \\
\text { months }\end{array}$ & $<0.0001$ \\
\hline Remacha et al. [40] & 263 & Retrospective & Median OS & 105 months & 133 months & $<0.001$ \\
\hline
\end{tabular}


Table 2 Clinical studies showing that iron chelation improves survival in patients with lower risk MDS [32-40].

However, it is problematic that patient populations were usually well characterized regarding disease-related risk factors but not characterized and stratified according to performance status. This problem introduces a possible bias because fitter patients may have been more likely to receive iron chelation.

A matched pair analysis from the Düsseldorf MDS Registry [34], which carefully matched for age, gender, MDS type and MDS risk groups, showed a significant survival advantage for ICT. However, the matching did not include performance score and comorbidities, because of a lack of respective data. Assuming that hematologists in Germany did not restrict iron chelation to fitter patients, the Düsseldorf data may reflect a true survival advantage of iron chelation therapy.

The European LeukemiaNet MDS (EUMDS) Registry also provided interesting data [41]. Overall survival of 192 chelated patients was significantly better when compared with a large control group of 573 non-chelated patients, even after adjustment for all relevant prognostic factors, i.e., age, sex, comorbidity, performance status, and number of RBC units transfused prior to start of chelation. Another advantage of this study is that it looked at survival from the point in time when patients reached the eligibility criteria for iron chelation. Therefore, long-lasting stable intervals between diagnosis and onset of transfusion dependency were not counted and thus not misinterpreted as prolonged survival due to ICT.

The Canadian MDS Registry prospectively measures frailty, comorbidity and disability. Leitch et al. recently analyzed overall survival (OS) by receipt of ICT, adjusting for these patient-related factors [42]. Predictive factors for OS were determined. A matched pair analysis considering age, revised IPSS score, severity of transfusion dependence (TD), time from MDS diagnosis to TD, and receipt of disease-modifying agents was conducted. Of 239 patients, 83 received ICT; frailty, comorbidity and disability did not differ from non-ICT patients. Median OS from TD was superior in ICT patients (5.2 vs. 2.1 years; $P<0.0001$ ). By multivariate analysis, not receiving ICT independently predicted inferior OS, (hazard ratio for death 2.0, $P=0.03$ ). In matched pair analysis, OS remained superior for ICT patients $(P=0.02)$. In this prospective, non-randomized analysis, receiving ICT was associated with superior OS in lower IPSS risk MDS, adjusting for age, frailty, comorbidity, disability, revised IPSS, TD severity, time to TD and receiving disease-modifying agents. This provides additional evidence that ICT may confer clinical benefit.

The only prospective randomized trial of ICT in MDS patients is TELESTO, a prospective multicenter study to investigate the clinical benefit of chelation therapy with deferasirox (ClinicalTrials.gov Identifier: NCT00940602). It turned out to be difficult to recruit patients for this trial in countries where DFX is licensed and reimbursed, and after much discussion with the FDA, the number of patients to be recruited was reduced from 630 to 210 . Meanwhile, patient accrual has been completed. While the statistical power of the trial may no longer be sufficient to provide unequivocal evidence of improved overall survival, we might still get a signal indicating that transfusion-dependent patients with lower risk MDS benefit from iron chelation therapy.

It is difficult to pinpoint how iron chelation provides a survival advantage to MDS patients. Data from a US registry showed that the rate of cardiac causes of death was somewhat lower, infections occurred less frequently, and other malignancies were very rare [39]. However, the differences were not statistically significant. The IRON2 study from Spain, which found significantly longer overall survival and leukemia-free survival in chelated patients with lower risk MDS, also demonstrated significantly longer event-free survival regarding cardiac complications [40]. As already alluded to, iron overload may not only be related to cardiomyopathy but also to atherosclerosis.

Data regarding a beneficial effect of iron chelation on AML transformation are controversial. While the Düsseldorf MDS Registry did not observe a tangible effect [34], the above-mentioned US registry found that iron chelation delays AML transformation [39].

\section{Treatment of iron overload in patients with MDS}

Iron chelation therapy in patients with transfusion-dependent MDS has been shown to be safe and effective [27, 43, 44]. Guidelines on ICT in MDS are often included in guidelines on MDS treatment in general. For example, the European LeukemiaNet Guideline on the diagnosis and treatment of primary MDS in adults includes a short segment on ICT [45], suggesting that this treatment should be considered in transfusion-dependent patients with RA, RARS, or MDS with isolated $5 q$ deletion and a serum ferritin level higher than $1000 \mathrm{ng} / \mathrm{mL}$ after approximately 25 units of red cells. In addition, MDS patients who are potential candidates for allo-SCT can be considered for appropriate iron chelation therapy prior to the conditioning regimen for transplantation. Guidelines on ICT in MDS are similar in different countries. They usually recommend chelation therapy for patients who have a certain transfusion history (usually at least 20 or 25 pRBC units), whose SF levels exceed a threshold of 1000 or $1500 \mathrm{ng} / \mu \mathrm{l}$, and who have lower risk MDS with a reasonable life expectancy, because such patients often receive longterm transfusion therapy that puts them at risk of developing clinical complications of iron overload. 
The most commonly used iron chelator is deferasirox. Physicians experienced in the field of ICT have adopted a gentle approach when starting the treatment [46]. It is useful to start with a low dose, i.e., a fixed dose of $500 \mathrm{mg} / \mathrm{d}$ (nowadays $360 \mathrm{mg} /$ day with the film-coated tablets, FCT). Patients are monitored regarding drug tolerability and the dose is increased in weekly increments of $5 \mathrm{mg} / \mathrm{kg}$, with a target dose of about $15 \mathrm{mg} / \mathrm{kg}$ (FCT) in patients with a low transfusion frequency of $<2$ PRBC per 4 weeks, about $20 \mathrm{mg} / \mathrm{kg}$ (FCT) in patients with an intermediate transfusions frequency, and $20-30 \mathrm{mg} / \mathrm{kg}$ (FCT) in patients with a transfusion frequency $>2$ PRBC per 4 weeks. This approach helps to avoid gastrointestinal adverse events and is intended to strengthen compliance, which is known to decay as a result of AEs and the lack of symptoms from iron overload. Patients should be well informed about possible GI adverse events. Diarrhea is the most common side effect of DFX, occurring more frequently in elderly MDS patients than in young thalassemia patients. To manage this side effect, it is useful to discontinue any laxatives, consider the use of loperamide, maintain hydration and try to administer DFX at night [47].

Mean creatinine concentrations in MDS patients during the EPIC trial and other clinical studies showed an initial $20 \%$ increase in serum creatinin. With proper dose adjustment of DFX, this is usually followed by a new steady state rather than progressive elevation $[48,49]$. In the US, iron chelation with deferasirox can be used in patients with a creatinine clearance above $40 \mathrm{ml} / \mathrm{min}$. However, close monitoring of renal function is required in elderly MDS patients with pre-existing chronic renal insufficiency, diabetes, hypertension and congestive heart failure.

Liver toxicity is not a problem of DFX treatment in daily clinical practice. Transaminase levels decrease with decreasing serum ferritin levels, indicating that ICT is beneficial rather than toxic for the liver of iron-overloaded patients [50]. Hepatotoxicity is rare, apparently confined to patients with pre-existing liver problems.

ICT has become more convenient with the new deferasirox formulation in the form of film-coated tablets, which are well tolerated and can be taken with or without a meal $[51,52]$. Anything that makes iron chelation easier to handle may help to improve patient adherence and thus carries the potential to improve survival.

\section{Iron overload and allogeneic stem cell transplantation (SCT)}

Even if patients undergo allo SCT without having developed transfusional IOL, they show a dramatic increase in serum transferrin saturation and the appearance of non-transferrin bound iron (NTBI) soon after receiving the conditioning regimen [53]. This is mainly due to chemotherapy-induced extinction of erythropoiesis, which is by far the greatest consumer of iron in the body. It is not known how much toxicity is caused by this phenomenon, which is expected to be aggravated in patients with iron overload.

Leitch et al. recently provided an excellent overview of IOL in the context of allogeneic hematopoietic stem cell transplantation (allo HSCT) [54]. Regarding the prevalence of IOL around SCT, they referred to Armand et al. [55] who conducted a prospective study of 48 patients with acute leukemia (AL) or MDS undergoing myeloablative HSCT, using magnetic resonance imaging (MRI) to estimate liver iron content (LIC) and cardiac iron. The median (and range) pre-HSCT value of serum ferritin was $1549 \mathrm{ng} /$ mL (20-6989); serum hepcidin, 59 ng/mL (10-468); labile plasma iron, 0 LPI units (0.0-0.9). Eighty-five percent of patients had hepatic iron overload (HIO), and $42 \%$ had significant HIO (LIC >/=5.0 mg/gdw). Only 1 patient had cardiac iron overload. There was a strong correlation between pre-HSCT serum ferritin and estimated LIC ( $r=0.75)$, which was mostly dependent on prior transfusion history. Serum hepcidin was appropriately elevated in patients with HIO. Labile plasma iron elevation was rare. A regression calibration analysis supported the hypothesis that elevated pre-HSCT LIC is significantly associated with inferior postHSCT survival. A second study examined patients with an SF above the ULN following SCT, excluding patients with confounding factors. Sixty-five of 104 patients survived beyond four years post-SCT, of whom 38 (58\%) had an elevated SF and 31 of 32 had increased LIC by MRI. The authors concluded that IOL occurs in a sizeable proportion of SCT patients, persists long term, and organ function may be affected [56]. If not quantified by MRI, the incidence of IOL in the context of allo SCT for MDS appears to be more frequent in the early post-transplant phase and to decrease over time, suggesting that confounding factors become less prevalent over time [57].

Regarding the prognostic impact of iron overload in the context of SCT, Leitch et al. looked at 37 studies, which included a variable proportion of patients in early or advanced disease phases and examined outcomes at different time points. Despite the marked heterogeneity of studies, a few general results and recommendations can be summarized.

(1) Multiple studies found a significant association between increased SF and shortened overall survival, but it is difficult to draw definitive conclusions because SF is confounded by inflammatory conditions. (2) Even if IOL is assessed by MRI to measure liver iron content, results regarding the prognostic impact of IOL are not consistent [57-60]. Armand et al. concluded that the results presented in their meta-analysis should not be interpreted to imply that iron is irrelevant in HSCT. The trends suggest a possible prognostic effect, although it does not appear as strong as 
suspected based on the ferritin-related literature, and it may be restricted to certain subgroups. [61]. (4) An increased risk of infectious complications, in particular, invasive fungal infections, appears to be an important component of the unfavorable influence of IOL. (5) There is only one study examining LPI, showing that detectable LPI was significant for bacteremia and day 100 non-relapse mortality [62]. (6) In the post-SCT setting, decreasing IOL by phlebotomy has been demonstrated to reduce SF and LIC, reduce elevated liver function test, and possibly improve organ function and GvHD. (7) In patients in whom phlebotomy is contraindicated or not tolerated, low doses of ICT may be used.

Altogether, MDS patients who are candidates for alloHSCT should be considered for iron chelation therapy prior to transplantation. The indication for iron chelation therapy during conditioning and during the post-transplant period remains to be defined.

\section{References}

1. Santini V, Girelli D, Sanna A, Martinelli N, Duca L, Campostrini $\mathrm{N}$, et al. Hepcidin levels and their determinants in different types of myelodysplastic syndromes. PLoS ONE. 2011;6(8).

2. Malcovati L, Della Porta MG, Strupp C, Ambaglio I, Kuendgen A, Nachtkamp K, et al. Impact of the degree of anemia on the outcome of patients with myelodysplastic syndrome and its integration into the WHO classification-based Prognostic Scoring System (WPSS). Haematologica. 2011;96(10):1433-40.

3. Malcovati L, Della Porta MG, Cazzola M. Predicting survival and leukemic evolution in patients with myelodysplastic syndrome. Haematologica. 2006;91:1588-90.

4. de Swart L, Smith A, Fenaux P, Bowen D, Sanz G, HellströmLindberg E, et al. Transfusion-dependency Is the most important prognostic factor for survival in 1000 newly diagnosed MDS patients with low- and intermediate-1 risk MDS in the European LeukemiaNet MDS registry. Blood. 2011;118(21):ASH abstract 2775.

5. Roy NB, Myerson S, Schuh AH, Bignell P, Patel R, Wainscoat JS, et al. Cardiac iron overload in transfusion-dependent patients with myelodysplastic syndromes. Br J Haematol. 2011;154(4):521-4.

6. Pascal L, Beyne-Rauzy O, Brechignac S, Marechaux S, Vassilieff D, Ernst O, et al. Cardiac iron overload assessed by T2* magnetic resonance imaging and cardiac function in regularly transfused myelodysplastic syndrome patients. Br J Haematol. 2013;162(3):413-5.

7. Wood JC, Otto-Duessel M, Aguilar M, Nick H, Nelson MD, Coates TD, et al. Cardiac iron determines cardiac T2*, T2, and $\mathrm{T} 1$ in the gerbil model of cardiomyopathy. Circulation. 2005;112:535-43.

8. Carpenter JP, He T, Kirk P, Roughton M, Anderson LJ, de Noronha SV, et al. On T2* magnetic resonance and cardiac iron. Circulation. 2011;123(14):1519-28.

9. Vinchi F, Muckenthaler MU, Da Silva MC, Balla G, Balla J, Jeney V. Atherogenesis and iron: from epidemiology to cellular level. Front Pharmacol. 2014;5:94.

10. Duffy SJ, Biegelsen ES, Holbrook M, Russell JD, Gokce N, Keaney JF Jr, et al. Iron chelation improves endothelial function in patients with coronary artery disease. Circulation. 2001;103(23):2799-804.
11. Cheung YF, Chan GCF, Ha SY. Effect of deferasirox (ICL670) on arterial function in patients with beta-thalassaemia major. $\mathrm{Br}$ J Haematol. 2008;141:728-33.

12. Okabe H, Suzuki T, Uehara E, Ueda M, Nagai T, Ozawa K. The bone marrow hematopoietic microenvironment is impaired in iron-overloaded mice. Eur J Haematol. 2014;93(2):118-28.

13. Zhang Y, Zhai W, Zhao M, Li D, Chai X, Cao X, et al. Effects of iron overload on the bone marrow microenvironment in mice. PLoS ONE. 2015;10(3):e0120219.

14. Bowen D, Wang L, Frew M, Kerr R, Groves M. Antioxidant enzyme expression in myelodysplastic and acute myeloid leukemia bone marrow: further evidence of a pathogenetic role for oxidative stres? Haematologica. 2003;88:1070-2.

15. Thompson JE, Conlon JP, Yang X, Sanchez PV, Carroll M. Enhanced growth of myelodysplastic colonies in hypoxic conditions. Exp Hematol. 2007;35(1):21-31.

16. Ghoti H, Amer J, Winder A, Rachmilewitz E, Fibach E. Oxidative stress in red blood cells, platelets, and polymorphonuclear leukocytes from patients with myelodysplastic syndromes. Eur J Haematol. 2007;79:463-7.

17. Novotna B, Bagryantseva Y, Siskova M, Neuwirtova R. Oxidative damage in bone marrow cells of patients with low-risk myelodysplastic syndrome. Leukemia Res. 2009;33:340-3.

18. Chung YJ, Robert C, Gough SM, Rassool FV, Aplan PD. Oxidative stress leads to increased mutation frequency in a murine model of myelodysplastic syndrome. Leuk Res. 2014;38(1):95-102.

19. Saigo K, Takenokuchi M, Hiramatsu Y, Tada H, Hishita T, Takata $\mathrm{M}$, et al. Oxidative stress levels in myelodysplastic syndrome patients: their relationship to serum ferritin and haemoglobin values. J Int Med Res. 2011;39(5):1941-5.

20. de Souza GF, Barbosa MC, Santos TE, Carvalho TM, de Freitas RM, Martins MR, et al. Increased parameters of oxidative stress and its relation to transfusion iron overload in patients with myelodysplastic syndromes. J Clin Pathol. 2013;66(11):996-8.

21. Lu W, Zhao M, Rajbhandary S, Xie F, Chai X, Mu J, et al. Free iron catalyzes oxidative damage to hematopoietic cells/mesenchymal stem cells in vitro and suppresses hematopoiesis in iron overload patients. Eur J Haematol. 2013;91(3):249-61.

22. Kikuchi S, Kobune M, Iyama S, Sato T, Murase K, Kawano $\mathrm{Y}$, et al. Improvement of iron-mediated oxidative DNA damage in patients with transfusion-dependent myelodysplastic syndrome by treatment with deferasirox. Free Radic Biol Med. 2012;53(4):643-8.

23. Westhofen G, Ganster C, Beier F, Rassaf T, Al-Ali HF, Stuhlmann $\mathrm{R}$, et al. Comprehensive genomic analysis provides further evidence that iron overload can induce genetic instability in myelodysplastic syndromes. Blood. 2015;126(23):2842.

24. Hartmann J, Braulke F, Sinzig U, Wulf G, Maas JH, Konietschke $\mathrm{F}$, et al. Iron overload impairs proliferation of erythroid progenitors cells (BFU-E) from patients with myelodysplastic syndromes. Leuk Res. 2013;37(3):327-32.

25. Prus E, Fibach E. Uptake of non-transferrin iron by erythroid cells. Anemia. 2011;2011:8 pages.

26. Taoka K, Kumano K, Nakamura F, Hosoi M, Goyama S, Imai Y, et al. The effect of iron overload and chelation on erythroid differentiation. Int J Hematol. 2012;95(2):149-59.

27. List AF, Baer MR, Steensma DP, Raza A, Esposito J, MartinezLopez N, et al. Deferasirox reduces serum ferritin and labile plasma iron in RBC transfusion-dependent patients with myelodysplastic syndrome. J Clin Oncol. 2012;30(17):2134-9.

28. Gattermann N, Finelli C, Della Porta M, Fenaux P, Stadler M, Guerci-Bresler A, et al. Hematologic responses to deferasirox therapy in transfusion-dependent patients with myelodysplastic syndromes. Haematologica. 2012;97(9):1364-71.

29. Nolte F, Höchsmann B, Giagounidis A, Lübbert M, Platzbecker U, Haase D, Lück A, Gattermann N, Taupitz M, Baier M, 
Leismann O, Junkes A, Schumann C, Hofmann WK, Schrezenmeier H. Results from a 1-year, open-label, single arm, multicenter trial evaluating the efficacy and safety of oral deferasirox in patients diagnosed with low and int-1 risk myelodysplastic syndrome (MDS) and transfusion-dependent iron overload. Ann Hematol. 2013;92(2):191-8.

30. Angelucci E, Santini V, Di Tucci AA, Quaresmini G, Finelli C, Volpe A, et al. Deferasirox for transfusion-dependent patients with myelodysplastic syndromes: safety, efficacy, and beyond (GIMEMA MDS0306 Trial). Eur J Haematol. 2014;92(6):527-36.

31. Jensen PD, Heickendorff L, Pedersen B, Bendix-Hansen K, Jensen FT, Christensen T, et al. The effect of iron chelation on haemopoiesis in MDS patients with transfusional iron overload. Br J Haematol. 1996;94:288-99.

32. Leitch HA, Leger CS, Goodman TA, Wong KK, Wong DHC, Ramadan KM, et al. Improved survival in patients with myelodysplastic syndrome receiving iron chelation therapy. Clin Leukemia. 2008;2:205-11.

33. Rose C, Brechignac S, Vassilief D, Pascal L, Stamatoullas A, Guerci A, Larbaa D, Dreyfus F, Beyne-Rauzy O, Chaury MP, Roy L, Cheze S, Morel P, Fenaux P, GFM (Groupe Francophone des Myélodysplasies). Does iron chelation therapy improve survival in regularly transfused lower risk MDS patients? A multicenter study by the GFM (Groupe Francophone des Myélodysplasies). Leuk Res. 2010;34(7):864-70.

34. Neukirchen J, Fox F, Kundgen A, Nachtkamp K, Strupp C, Haas $\mathrm{R}$, et al. Improved survival in MDS patients receiving iron chelation therapy-a matched pair analysis of 188 patients from the Dusseldorf MDS registry. Leuk Res. 2012;36(8):1067-70.

35. Neukirchen J, Germing U, Fox F, Glaser S, Gattermann N. The impact of iron chelation therapy on clinical outcomes in realworld lower-risk patients with myelodysplastic syndromes (MDS): results from the $\mathrm{D} \sqrt{ }{ }^{\circ}$ sseldorf registry. Haematologica. 2012;97(s1):144.

36. Komrokji RS, Al Ali NH, Padron E, Lancet JE, List AF. Impact of iron chelation therapy on overall survival and AML transformation in lower risk MDS patients treated at the Moffitt Cancer Center. Blood. 2011;118:2776 (abstract).

37. Zeidan AM, Hendrick F, Friedman E, Gore SD, Baer MR, Sasane $\mathrm{M}$, et al. Deferasirox is associated with reduced mortality risk in a Medicare population with myelodysplastic syndromes. Blood. 2012;120(21):426.

38. Delforge M, Selleslag D, Beguin Y, Triffet A, Mineur P, Theunissen $\mathrm{K}$, et al. Adequate iron chelation therapy for at least six months improves survival in transfusion-dependent patients with lower risk myelodysplastic syndromes. Leuk Res. 2014;38(5):557-63.

39. Lyons RM, Marek BJ, Paley C, Esposito J, McNamara K, Garbo $\mathrm{L}$, et al. Relationship between chelation and clinical outcomes in lower-risk patients with myelodysplastic syndrome (MDS): registry analysis at 5 years. Blood. 2014;124(21):1350.

40. Remacha AF, Arrizabalaga B, Villegas A, Duran MS, Hermosin L, de Paz R, et al. Evolution of iron overload in patients with lowrisk myelodysplastic syndrome: iron chelation therapy and organ complications. Ann Hematol. 2015;94(5):779-87.

41. Langemeijer S, De Swart L, Yu G, Smith A, Crouch S, Johnston T, Fenaux P, Symeonidis A, Cermak J, Hellstrom-Lindberg E, Sanz G, Stauder R, Malcovati L, Germing U, Holm MS, Mittelman M, Madry K, Tatic A, Almeida A, Savic A, Park S, Beyne-Rauzy O, Itzykson R, van Marrewijk C, Bowen D, de Witte T. Impact of treatment with iron chelators in lower-risk MDS patients participating in the European Leukemianet MDS (EUMDS) Registry. Blood. 2016;128:3186 (abstract).

42. Leitch HA, Parmar A, Wells RA, Chodirker L, Zhu N, Nevill TJ, et al. Overall survival in lower IPSS risk MDS by receipt of iron chelation therapy, adjusting for patient-related factors and measuring from time of first red blood cell transfusion dependence: an MDS-CAN analysis. Br J Haematol. 2017.

43. Cappellini MD, Porter J, El-Beshlawy A, Li CK, Seymour JF, Elalfy M, et al. Tailoring iron chelation by iron intake and serum ferritin: the prospective EPIC study of deferasirox in 1744 patients with transfusion-dependent anemias. Haematologica. 2010;95(4):557-66.

44. Gattermann N, Finelli C, Della Porta M, Fenaux P, Ganser A, Guerci-Bresler A, et al. Deferasirox in iron-overloaded patients with transfusion-dependent myelodysplastic syndromes: results from the large 1-year EPIC study. Leuk Res. 2010;34:1143-50.

45. Malcovati L, Hellstrom-Lindberg E, Bowen D, Ades L, Cermak J, Del Canizo C, et al. Diagnosis and treatment of primary myelodysplastic syndromes in adults: recommendations from the European LeukemiaNet. Blood. 2013;122(17):2943-64.

46. Nolte F, Angelucci E, Breccia M, Gattermann N, Santini V, Vey $\mathrm{N}$, et al. Updated recommendations on the management of gastrointestinal disturbances during iron chelation therapy with Deferasirox in transfusion dependent patients with myelodysplastic syndrome-emphasis on optimized dosing schedules and new formulations. Leuk Res. 2015;39(10):1028-33.

47. Nolte F, Angelucci E, Beris P, Macwhannell A, Selleslag D, Schumann C, et al. Clinical management of gastrointestinal disturbances in patients with myelodysplastic syndromes receiving iron chelation treatment with deferasirox. Leuk Res. 2011;35(9):1131-5.

48. Gattermann N, Schmid M, Della Porta M, Taylor K, Seymour JF, Habr D, et al. Efficacy and safety of deferasirox (Exjade) during 1 year of treatment in transfusion-dependent patients with myelodysplastic syndromes: results from EPIC trial. Blood. 2008;112(11):633.

49. Schmid M, Cappellini MD, Porter JB, Greenberg PL, Lawniczek $\mathrm{T}$, Glaser S, et al. Safety of Deferasirox (Exjade $Æ)$ in myelodysplastic syndromes (MDS) and non-MDS patients with transfusional iron overload: a pooled analysis focusing on renal function. Blood. 2009;114(22):1768.

50. Gattermann N, Schmid M, Guerci-Bresler A, Della Porta M, Taylor K, Habr D, et al. Correlation between decreased serum ferritin and improved liver transaminases during Deferasirox (Exjade ${ }^{\circledR}$ ) treatment in iron-overloaded patients with myelodysplastic syndromes. Blood. 2009;114(22):3803.

51. Taher AT, Origa R, Perrotta S, Kouraklis A, Ruffo GB, Kattamis A, et al. New film-coated tablet formulation of deferasirox is well tolerated in patients with thalassemia or MDS: results of the randomized, phase II E.C.L.I.P.S.E. study. Blood. 2016;128(22):1285.

52. Taher AT, Origa R, Perrotta S, Kouraklis A, Ruffo GB, Kattamis A, et al. Improved patient-reported outcomes with a film-coated versus dispersible tablet formulation of deferasirox: results from the randomized, phase II E.C.L.I.P.S.E. Study. Blood. 2016;128(22):850.

53. Sahlstedt L, Ebeling F, von Bonsdorff L, Parkkinen J, Ruutu T. Non-transferrin-bound iron during allogeneic stem cell transplantation. Br J Haematol. 2001;113:836-8.

54. Leitch HA, Fibach E, Rachmilewitz E. Toxicity of iron overload and iron overload reduction in the setting of hematopoietic stem cell transplantation for hematologic malignancies. Crit Rev Oncol Hematol. 2017;113:156-70.

55. Armand P, Kim HT, Rhodes J, Sainvil MM, Cutler C, Ho VT, et al. Iron overload in patients with acute leukemia or MDS undergoing myeloablative stem cell transplantation. Biol Blood Marrow Transplant. 2011;17(6):852-60.

56. Rose C, Ernst O, Hecquet B, Maboudou P, Renom P, Noel MP, et al. Quantification by magnetic resonance imaging and liver consequences of post-transfusional iron overload alone in long term survivors after allogeneic hematopoietic stem cell transplantation (HSCT). Haematologica. 2007;92(6):850-3. 
57. Meyer SC, O’Meara A, Buser AS, Tichelli A, Passweg JR, Stern M. Prognostic impact of posttransplantation iron overload after allogeneic stem cell transplantation. Biol Blood Marrow Transplant. 2013;19(3):440-4.

58. Bazuaye GN, Buser A, Gerull S, Tichelli A, Stern M. Prognostic impact of iron parameters in patients undergoing allo-SCT. Bone Marrow Transplant. 2012;47(1):60-4.

59. Grossekatthofer M, Guclu ED, Lawitschka A, Matthes-Martin S, Mann G, Minkov M, et al. Ferritin concentrations correlate to outcome of hematopoietic stem cell transplantation but do not serve as biomarker of graft-versus-host disease. Ann Hematol. 2013;92(8):1121-8.

60. Virtanen JM, Itala-Remes MA, Remes KJ, Vahlberg T, Saunavaara JP, Sinisalo M, et al. Prognostic impact of pretransplant iron overload measured with magnetic resonance imaging on severe infections in allogeneic stem cell transplantation. Eur J Haematol. 2013;91(1):85-93.

61. Armand P, Kim HT, Virtanen JM, Parkkola RK, Itala-Remes MA, Majhail NS, et al. Iron overload in allogeneic hematopoietic cell transplantation outcome: a meta-analysis. Biol Blood Marrow Transplant. 2014;20(8):1248-51.

62. Wermke M, Eckoldt J, Goetze K, Klein SA, Bug G, Stölzel F. The extent of labile plasma iron (LPI) predicts for non-relapse-mortality (NRM) in AML and MDS patients with systemic iron overload undergoing allogenic stem cell transplantation. Results of the prospective, German-Austrian ALLIVE trial. Blood. 2015;126(23).

63. Leitch HA, Goodman TA, Wong KK, Vickars LM, Galbraith PF, Leger CS. Improved survival in patients with myelodysplastic syndrome (MDS) receiving iron chelation therapy. Blood (ASH Annual Meeting Abstracts). 2006;108:249 (abstract). 